\title{
Specific approach for continuous air quality monitoring
}

\author{
Predrag M. Živkovići ${ }^{1}$, Mladen A. Tomić ${ }^{1}$, Gradimir S. Ilić ${ }^{1}$, Mića V. Vukić ${ }^{1}$, Žana Ž. Stevanović ${ }^{2}$ \\ ${ }^{1}$ University of Niš, Faculty of Mechanical Engineering, Niš, Serbia \\ ${ }^{2}$ University of Belgrade, Institute for Nuclear Sciences Vinča, Laboratory for Thermal Engineering and Energy, Belgrade, \\ Serbia
}

\begin{abstract}
Rapid industry development as well as increase of traffic volume across the world have resulted in air quality becoming one of the most important factors of everyday life. Air quality monitoring is the necessary factor for proper decision making regarding air pollution. An integral part of such investigations is the measurement of wind characteristics, as the wind is the most influential factor in turbulent pollution diffusion into the atmosphere. The most of the air pollution originates from combustion processes, so it is important to make quantitative, as well as qualitative analysis, as the sources of pollution can be very distant. In this paper, specific methodology for continuous wind, temperature and air quality data acquisition is presented. Comparison of the measured results is given, as well as the detailed presentation of the characteristics of the acquisition software used.
\end{abstract}

Keywords: air quality, atmospheric conditions, acquisition software, wind data, $\mathrm{CO}_{2}$.

\section{SCIENTIFIC PAPER}

UDC 502.3.681.5.08

Hem. Ind. 66 (1) 85-93 (2012)

doi: 10.2298/HEMIND110525066Z

Available online at the Journal website: http://www.ache.org.rs/HI/

Since the Industrial Revolution, the mankind is dealing with increasing pollution problems. The main pollution sources are the side effects of manufacturing, mining, transportation, and power production. The effects on the human standard of living, number of people affected and the applied technology [1] are usually taken as the measure the pollutant emissions impacts to the environment. As the air pollution increases, the effort to understand the related phenomena consequentially increases. Extensive research is being done on some of the pollution aspects.

Many authors are giving their contribution by using different measuring techniques. Researchers always have on their mind that equipment needed for air pollution is relatively expensive, and as such not easily available to everyone. It is possible to conduct the research by monitoring multiple pollution components [2-8,11], or a single one but with multiple instruments and measuring locations $[5,6,9,12]$. Some research is done through long-term measurements [11,12], and some with relatively short-therm, but with high frequency $[9,10]$. A number of studies has been done on $\mathrm{CO}_{2}$ level monitoring, which is expected, considering growing global warming problems [6,7,9-11]. A lot of studies compare measured and model or numerical data $[3-5,8]$. A number of authors apply detailed statistical analysis [10]. As the locations of the sources are very important, it was shown that it is possible to de-

Correspondence: P.M. Živković, Faculty of Mechanical Engineering, Aleksandra Medvedeva 14, 18000 Niš, Serbia.

E-mail: pzivkovic@masfak.ni.ac.rs

Paper received: 25 May, 2011

Paper accepted: 20 September, 2011 tect the sources of pollution, if the wind data are known [8].

It is obvious that proper estimation of the pollutant emission level is of vital importance. As the refference component for the measurements, concentration of $\mathrm{CO}_{2}$ was chosen. Reasons for such decision were the chemical inertiality and the relatively high concentration of $\mathrm{CO}_{2}$ in the atmosphere, which allows it to be used as the tracer gas. Although $\mathrm{CO}_{2}$ is denser than air, it can be assumed that all other components of the flue gasses will be distributed similarly. The fact is that for simulations of urban pollution distribution usually $\mathrm{SF}_{6}$ was used, and its density is $6.12 \mathrm{~kg} / \mathrm{m}^{3}$, which is considerably higher than $1.98 \mathrm{~kg} / \mathrm{m}^{3}$ for $\mathrm{CO}_{2}$ (both for atmospheric pressure and $0{ }^{\circ} \mathrm{C}$ ). As of January $1^{\text {st }} 2006$, $\mathrm{SF}_{6}$ was banned as the tracer gas, some other solution had to be found. Under such conditions, it can be accepted that $\mathrm{CO}_{2}$ as a main flue gas component can indicate the distribution of all the other components.

\section{MONITORING EQUIPMENT}

As can be seen in Figure 1, the District Heating Plant "Krivi Vir" is located in the center of the City of Niš. It is surronded with high buildings, mostly over 7 floors high. This means that there are about 50,000 people directly and highly influenced by the plant. The plant power is $130 \mathrm{MW}$. The situation was much improved when fuel was changed from heavy oil to natural gas in 2006. Recent measurements shows that flue gasses on the exhaust collector contain 0-1 ppm CO, 1-2 ppm NO and about $50 \mathrm{ppm} \mathrm{NO} \mathrm{NO}_{2}$ and $\mathrm{NO}_{x}$. This indicates that the main components are $\mathrm{CO}_{2}$ and $\mathrm{H}_{2} \mathrm{O}$, which justifies the choice of $\mathrm{CO}_{2}$ as the reference gas. 
The district heating plant is located near to the $\mathrm{Ni}$ šava river, so the monitoring sites were chosen also to be located near to the river. Monitoring Site 1 is located on the upstream, and Monitoring Site 2 on the downstream side of the plant. It is supposed that this arrangement can assure the separation of $\mathrm{CO}_{2}$ imission from the plant and the rest of the sources (individual heating, road traffic, organic waste etc.), which were treated separately.

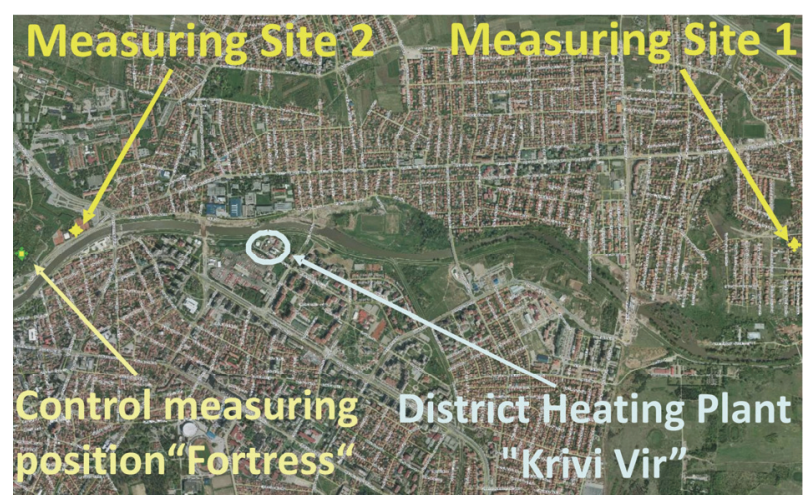

Figure 1. Monitoring sites and district heating plant disposition.

Monitoring Sites were chosen in order to determine specific conditions of pollutant emission in the City of Niš. Monitoring Site 1 represents individual heating, as being positioned in the suburbia. Monitoring Site 2 represents influence of the traffic, as being located nearby crossroad with very high traffic intensity. Control monitoring site, located in the city fortress, represent green area, as being mostly forested. This is also the location of the main meteorological station. River Nišava flows through the centre of the domain. All measuring positions were used to determine the influence of the District Heating Plant „Krivi Vir“, as one of the largest pollution sources in the city (also 31.3\% of total $\mathrm{CO}_{2}$ emission) [6].

\section{$\mathrm{CO}_{2}$ measurement}

Measurements were performed from december 2008 to december 2010. The validation of the data measured on the Monitoring Sites 1 and 2 was done by measuring $\mathrm{CO}_{2}$ imission in the control measuring position, which is presented in Figures 2 and 3. These control measurements were done by TESTO 454 gas analyser. The measurements are slightly different (difference is constant and can be removed statistically). Yet, it is important that both measurements shows the significant decrease of $\mathrm{CO}_{2}$ concentration at the end of the heating season (marked with circle on both diagrams). This shows that the start predictions are correct, and that these measurements, after thorough analysis, can indicate the $\mathrm{CO}_{2}$ distribution into the atmosphere.

In the Table 1, properties of the used $\mathrm{CO}_{2}$ sensor module are presented.

\section{Wind speed and direction measurement}

As all the processes in the atmospheric boundary layer are highly influenced by the wind, basic monitoring data are the wind speed and direction. Usually, cup anemometers are used. For the reason of comparing measured data on chosen locations with the long-term, stable measured data from the main meteorological station, $10 \mathrm{~m}$ mast for cup anemometer positioning was used. In Table 2 the properties of the used cup anemometer are presented.

\section{Temperature sensors and data logger data}

Temperature measurements were performed in order to assess the atmospheric stability. In cooperation with the Ecoterra company, the Akvi Data logger and

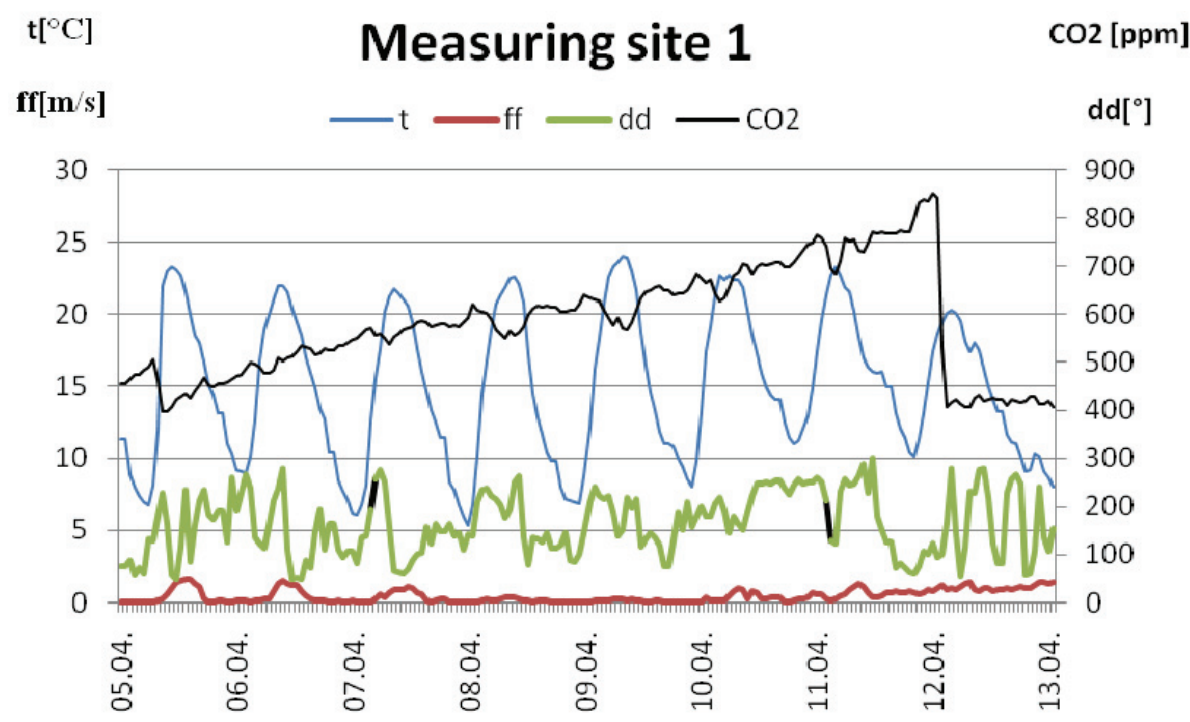

Figure 2. Monitoring Site 1 results for beginning of April 2009. 


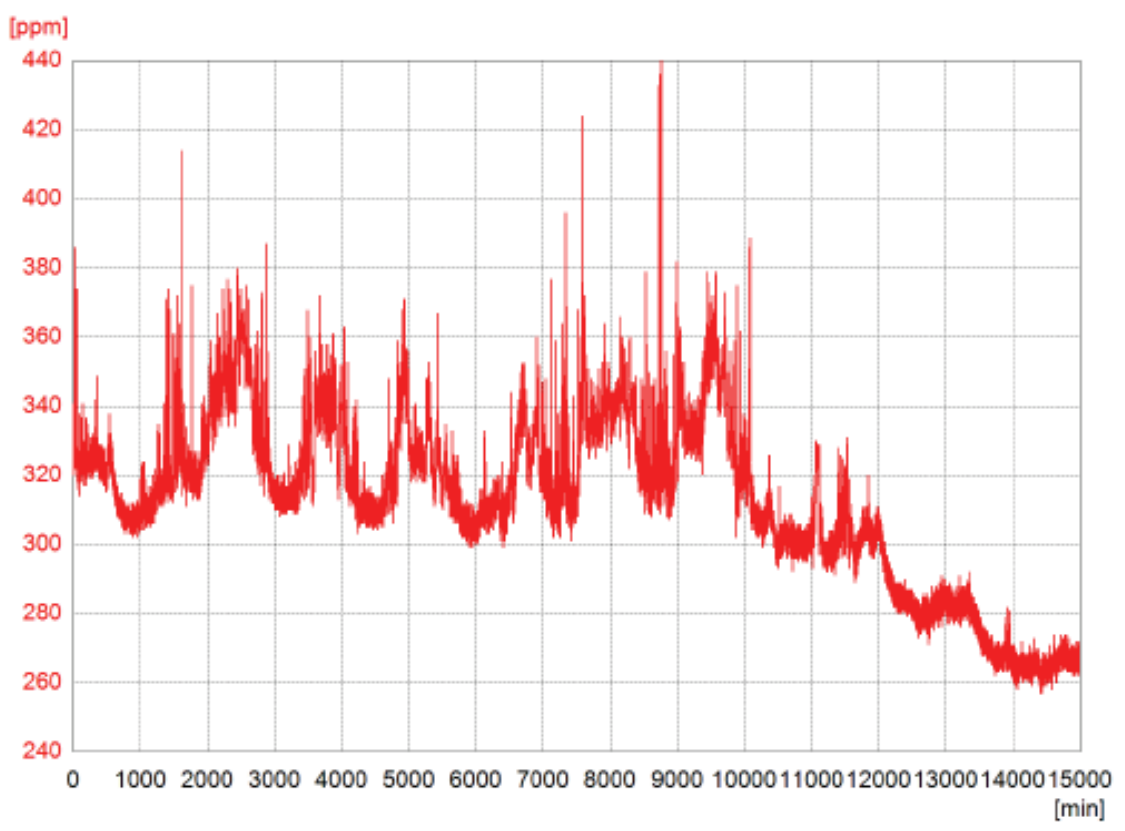

Figure 3. Control Monitoring Site results for beginning of April 2009.

appropriate software were developed. The properties of the used temperature sensors and Akvi data logger are given in Table 3.

Table 1. $\mathrm{CO}_{2}$ sensor technical data (concentration measurement)

\begin{tabular}{lc}
\hline Measuring range & $350-10000 \mathrm{ppm} \mathrm{CO}$ \\
Accuracy & $\pm 20 \%$ at $1000 \mathrm{ppm} \mathrm{CO} 2$ \\
Temperature range & $-10-50{ }^{\circ} \mathrm{C}$ \\
Rel. humidity range & $5-95 \% \mathrm{RH}$ \\
Acquisition speed & 1 sample/s \\
\hline
\end{tabular}

Table 2. Cup anemometer technical data

\begin{tabular}{lcc}
\hline Parameter & $\begin{array}{c}\text { Wind speed } \\
\text { measurement }\end{array}$ & $\begin{array}{c}\text { Wind direction } \\
\text { measurement }\end{array}$ \\
\hline Measuring range & $0.5-50 \mathrm{~m} / \mathrm{s}$ & $0-360^{\circ}$ \\
Accuracy & $\pm 0.1 \mathrm{~m} / \mathrm{s}$ & $\pm 0.1^{\circ}$ \\
Temperature range & $-40-80{ }^{\circ} \mathrm{C}$ & $-40-80{ }^{\circ} \mathrm{C}$ \\
Relative humidity range & $0-100 \% \mathrm{RH}$ & $0-100 \% \mathrm{RH}$ \\
Acquisition speed & 2 samples/s & 2 samples $/ \mathrm{s}$ \\
\hline
\end{tabular}

\section{Acquisition software}

A multi-channel program package DSD8csIP v1.0s was developed in cooperation with the Digital Smart Devices company. The software package consists of two parts: Server (computer connected to the logger) and Client (any computer that can access the Server via local and/or global network).

The server application is shown in Figure 4. Two types of data are presented: simultaneous monitoring of all measuring channels (on the left side, part Trenutna akvizicija), and presentation of previous mesurements (on the right side, part Vremenska akvizicija).

Table 3. Manufacturer's specifications for the temperature sensors and Akvi data logger (sensor type and position: as needed; direct coupling with PSI: data logger; application software: author)

\begin{tabular}{|c|c|c|}
\hline \multirow{2}{*}{ Property } & \multicolumn{2}{|c|}{ Temperature sensor type } \\
\hline & TP 11, DREV 1F & TP 21, DREV 2F \\
\hline \multicolumn{3}{|c|}{ Basic data } \\
\hline Operating range & $-40-125^{\circ} \mathrm{C}$ & $-50-150^{\circ} \mathrm{C}$ \\
\hline Resolution & \multicolumn{2}{|c|}{$0.06^{\circ} \mathrm{C}$} \\
\hline Accuracy & $0.05^{\circ} \mathrm{C}$ & $0.1^{\circ} \mathrm{C}$ \\
\hline Responce & $1 \mathrm{~s}$ & $20 \mathrm{~s}$ \\
\hline \multicolumn{3}{|c|}{ Electronic routing compatibility } \\
\hline Communication & \multicolumn{2}{|c|}{ Differential, 4 wire } \\
\hline Voltage & \multicolumn{2}{|c|}{$12 \mathrm{~V}$} \\
\hline Communication type & \multicolumn{2}{|c|}{ Serial } \\
\hline Power supply & \multicolumn{2}{|c|}{$20 \mathrm{~mA}$ per driver } \\
\hline Driver connecting & \multicolumn{2}{|c|}{ Paralel } \\
\hline Max. No. of drivers & \multicolumn{2}{|c|}{32} \\
\hline Channels per driver & 8 & 4 \\
\hline
\end{tabular}

Channel adjusting is possible from the client, as well as from the server side. Client part of the ensures safe and immediate insight into the measured environment. In Figure 5, table presentation of all channel configuration is shown.

For the purposes of wind speed and direction, $\mathrm{CO}_{2}$ concentration and temperature, a modification of the Client part of the software package was made. It was more suitable for the real case, considering that there 


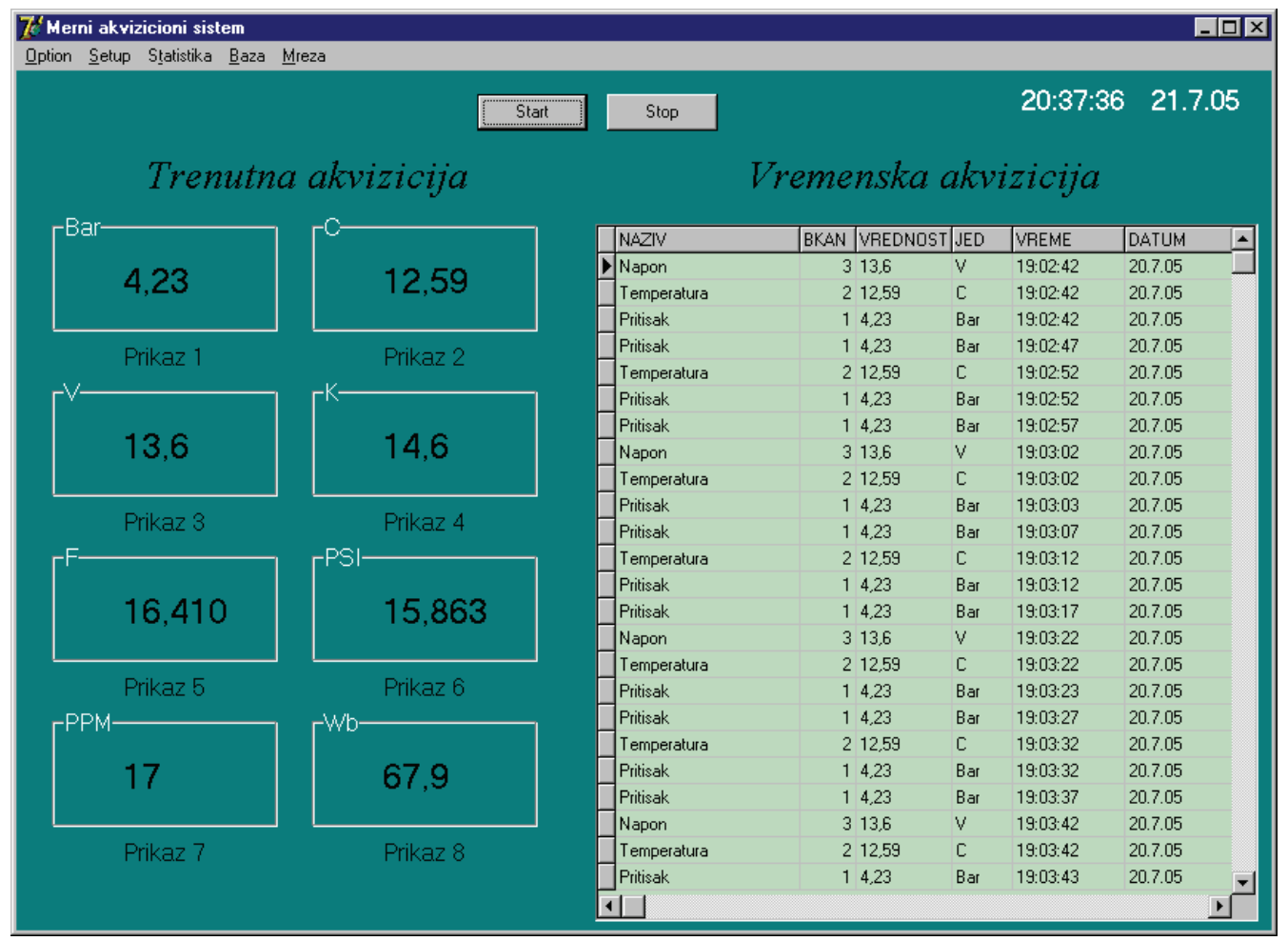

Figure 4. Main form of data presentation with menus for system adjusting.

\begin{tabular}{|c|c|c|c|c|c|c|c|c|c|c|c|c|c|c|}
\hline \multicolumn{13}{|c|}{$7 E^{\prime}$ Prikaz konfiguracije kanala } & \multicolumn{2}{|c|}{$-\square \times$} \\
\hline & PRIKAZ & KANAL & NAZIV & JED & TIP & MINKVANT & MINJJED & MAXKVANT & MAXJED & LINEAR & TIMERJED & VREDNOST & DEC & $\Delta$ \\
\hline 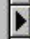 & 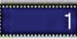 & 1 & Pritisak & Bar & 1 & 0 & 0,5 & 4095 & 20 & 0 & 1 & 5 & 2 & $\square$ \\
\hline & 2 & 2 & Temperatura & C & 1 & 0 & 0 & 4095 & 20 & 0 & 1 & 10 & 2 & \\
\hline & 3 & 3 & Napon & V & 1 & 0 & 0 & 4095 & 20 & 0 & 1 & 20 & 1 & \\
\hline & 4 & 4 & Faranhajt & K & 1 & 0 & 0 & 4095 & 20 & 0 & 0 & 100 & 1 & \\
\hline & 5 & 5 & Kapacitivnost & $\mathrm{F}$ & 1 & 0 & 0 & 4095 & 20 & 0 & 3 & 1 & 3 & \\
\hline & 6 & 6 & $\operatorname{mini} P$ & PSI & 1 & 0 & 0 & 4095 & 20 & 0 & 2 & 90 & 3 & \\
\hline & 7 & 7 & Koncentracija & PPM & 1 & 0 & 0 & 4095 & 20 & 0 & 3 & 1 & 0 & \\
\hline & 8 & 8 & $\mathrm{H} 1$ & wb & 1 & 0 & 0 & 4095 & 67.9 & 1 & 0 & 10 & 1 & \\
\hline
\end{tabular}

Figure 5. Table presentation of channel configuration form.

was a need for operating partially in PC Logger mode, and partially in Data Logger mode. The modification was named PCLOG v.1 (Figure 6).

This modification calls all available sensors in RS232-RS485 network. Measured data are saved into the database. Instantenous values, as well as the values from the current database, are showed graphically.

Single channel adjusting is possible, as the sampling time is a very important parameter. Also, channel description is possible, if change in data collected is needed (namely, if concentration of $\mathrm{CO}$ instead of $\mathrm{CO}_{2}$ is needed, etc.). Channel position is also changeable, if needed.

\section{MEASURED DATA}

The methodology presented was part of the research on the Thermal Engineering Department at the
Faculty of Mechanical Engineering, University of Niš. The basic idea was increasing the knowledge database, and improving atmospheric conditions monitoring and simulation. The usual procedure involves sampling air on a single location in the city, and then distributing the results according to, usually, very simple and often insufficient models.

In order to improve atmospheric conditions modelling, a specific system was developed. The model size, presented in Figure 1, is $16 \mathrm{~km}^{2}$, and represents the urban core of the city of Niš. Main wind directions are North-West and East, following Morava and Nišava river valleys. Data on Monitoring Sites 1 and 2 will be compared for the start of the heating season 2009/ /2010. All the data will be used for validation of the numerical simulations. 


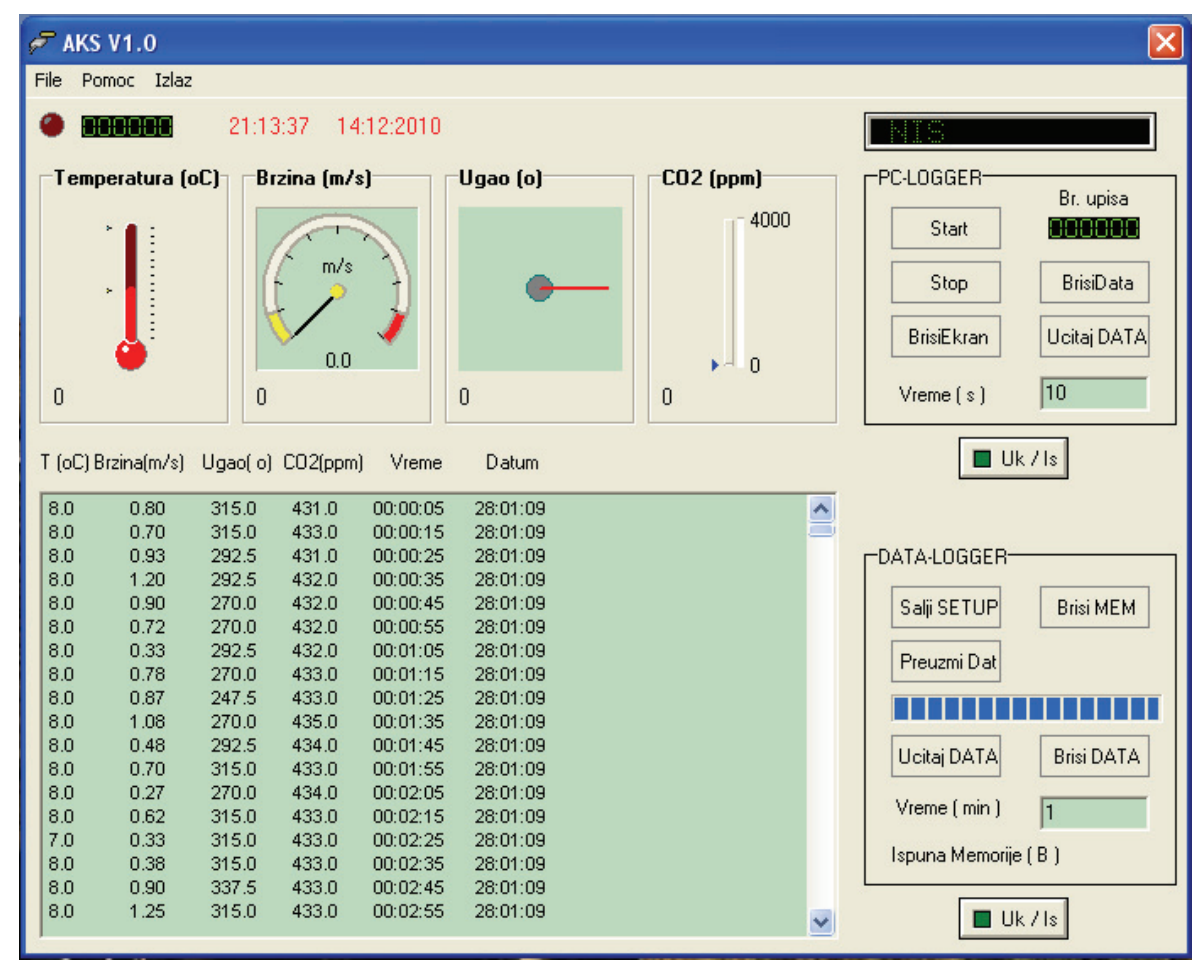

Figure 6. Main data presentation form with menus for system adjusting in PCLOG v.1 mode.

As can be seen in Figures 7-9, it is obvious that there are differences in wind frequency and direction. The reason for this is that the Main Meteorological Station Niš is less influenced by the surrounding objects than Monitoring Sites 1 and 2. Figure 9 clearly shows the main wind directions in Niš. As Monitoring Sites 1 and 2 are very close to the river, the larger influence of the East-West wind directions is obvious.

\section{DISCUSSION OF THE MEASURED RESULTS}

Figures 10 and 11 show results for $\mathrm{CO}_{2}$ concentration, wind direction and speed and temperature measurements on Monitoring Sites 1 and 2 are shown

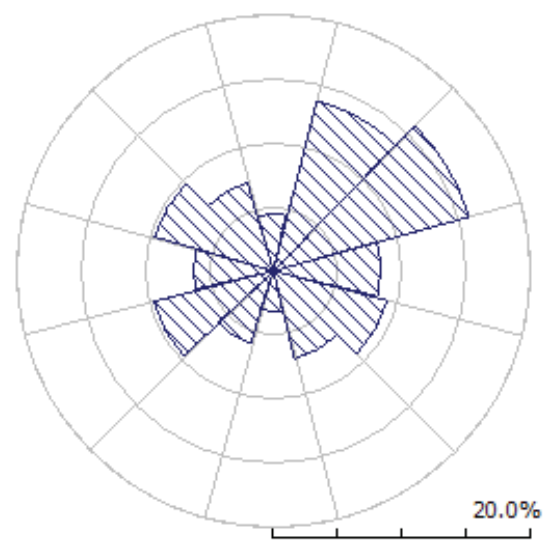

(a) for the period 30.09.2009-24.10.2009, which includes the start of the heating season, October $15^{\text {th }}$. The differences in the shape of the data presented are a result of the different sampling procedures.

Results shown in Figure 10 are obtained by sampling all data in 10 s intervals. Results shown in Figure 11 are sampled in $1 \mathrm{~s}$ intervals, and then averaged over $300 \mathrm{~s}$ (5 min) intervals. As it is obvious that the latter methodology gives a much more precise representation of the atmospheric conditions, it was adopted for the later work.

On the other hand, both groups of results indicate the same behaviour for all measured quantities, al-

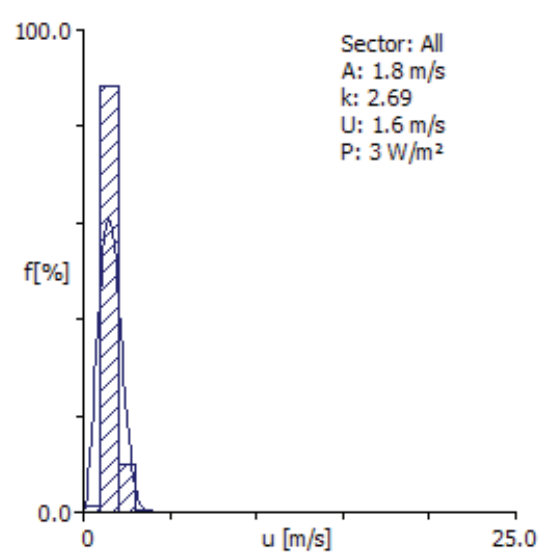

(b)

Figure 7. Measuring Position 1-a) wind rose; b) Weibull distribution. 


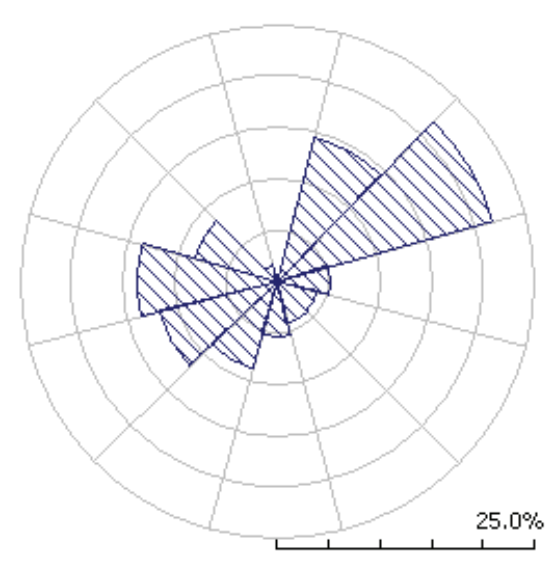

(a)

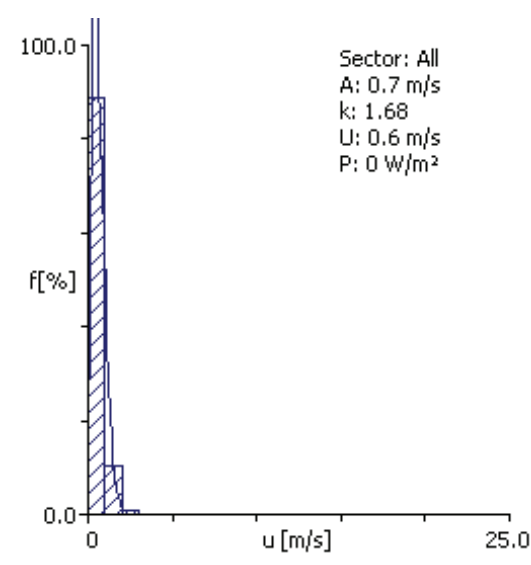

(b)

Figure 8. Measuring Position 2-a) wind rose; b) Weibull distribution.

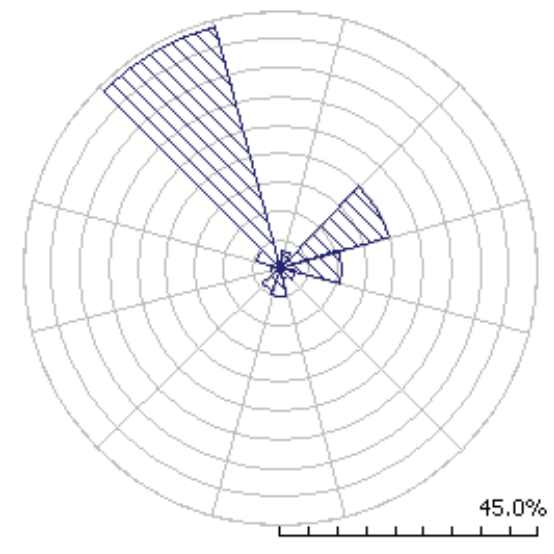

(a)

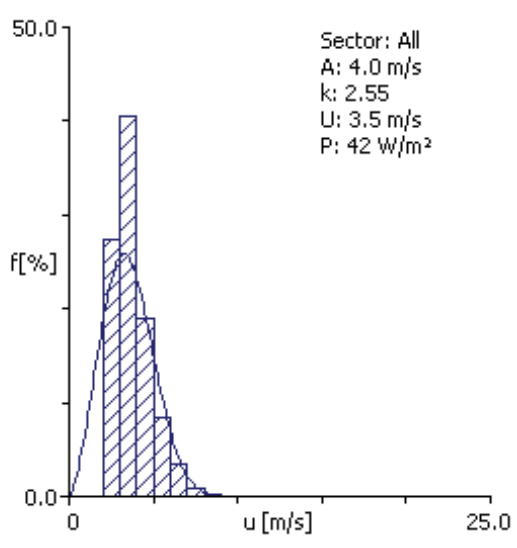

(b)

Figure 9. Meteorological Station Niš -a) wind rose; b) Weibull distribution.

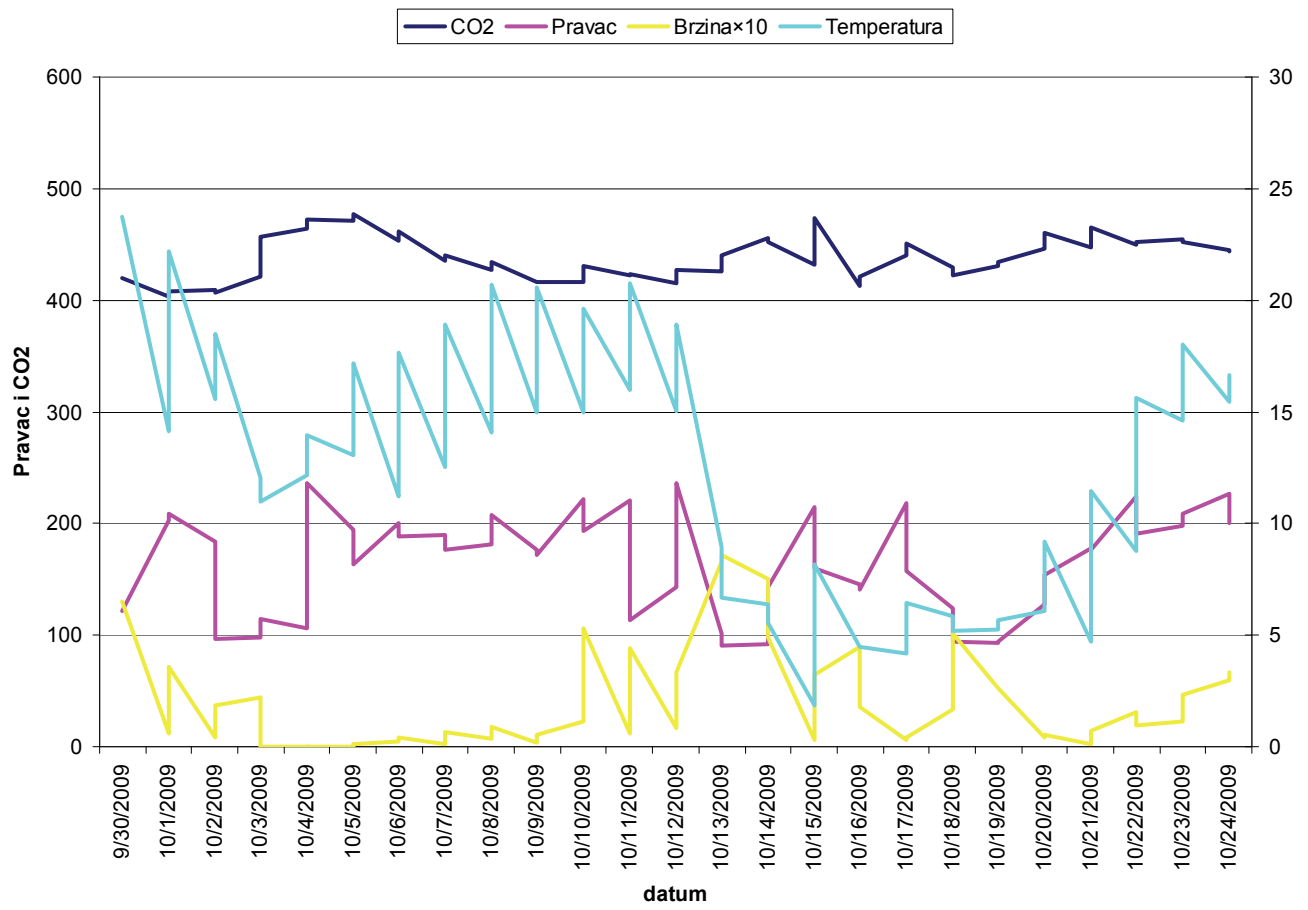

Figure 10. $\mathrm{CO}_{2}$ concentration, wind data and temperature measured on the Monitoring Site 1. 


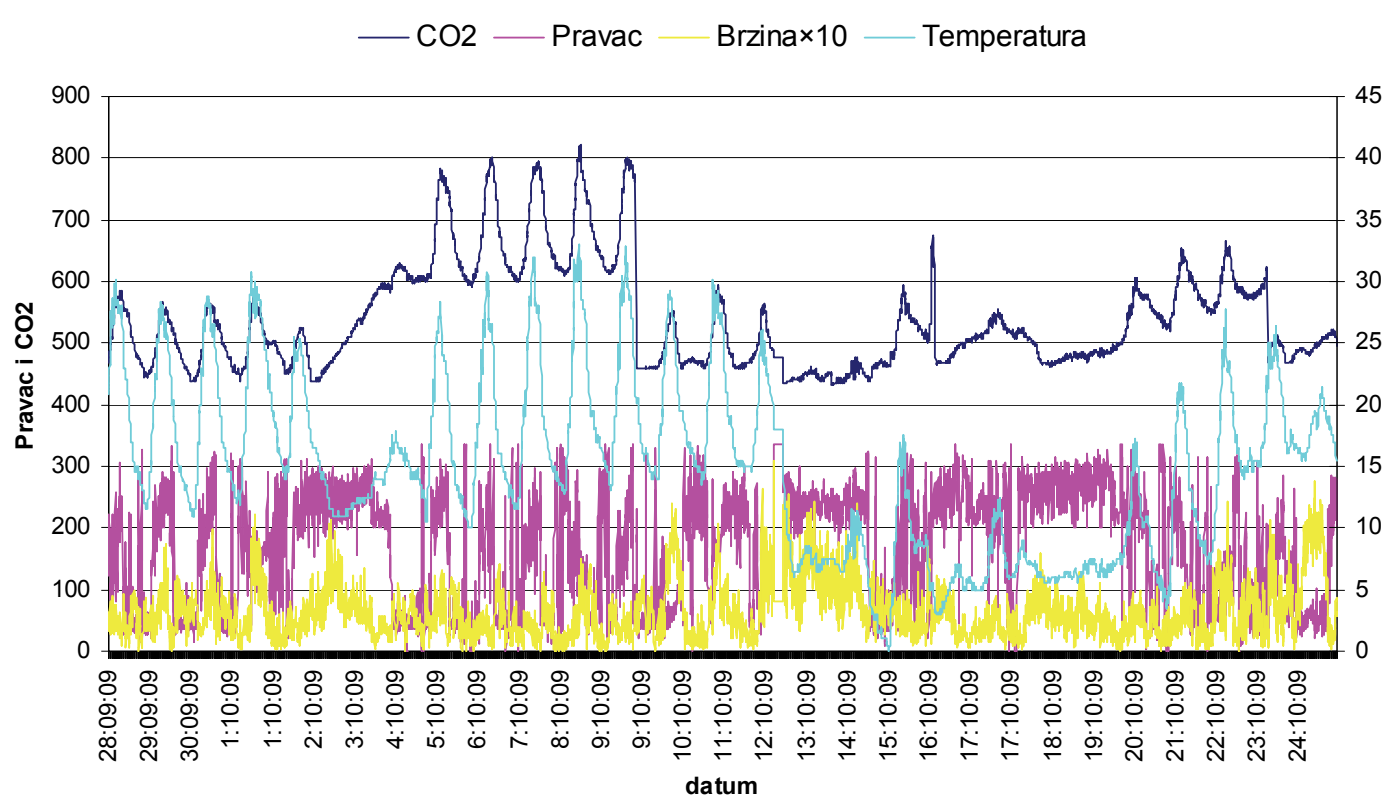

Figure 11. $\mathrm{CO}_{2}$ concentration, wind data and temperature measured on the Monitoring Site 2.

though in much more detail for the Monitoring Site 2. One can observe the dependence of the $\mathrm{CO}_{2}$ concentrations on the time of day (due to the traffic, before the start of the heating season), as well as on the mean temperature (start of the heating, which leads to a sharp increase of the mean daily concentration levels).

It can be clearly noticed in Figure 11 that the $\mathrm{CO}_{2}$ concentration level varies between 440 and 590 ppm until the beginning of October. The observed temperatures vary between 12 and $30^{\circ} \mathrm{C}$. Then, in the night between October $2^{\text {nd }}$ and October $3^{\text {rd }}$ the temperature drops to $10{ }^{\circ} \mathrm{C}$, and daily maximum to $18{ }^{\circ} \mathrm{C}$. In response, the individual heating started, which leaded to sharp increase of the $\mathrm{CO}_{2}$ concentration level, which stabilized between 600 and $800 \mathrm{ppm}$. On the other hand, from October $5^{\text {th }}$, the temperature returned to the previous level, but the heating obviously continued, which led to the highest $\mathrm{CO}_{2}$ concentration value of 820 ppm on October $8^{\text {th }}$, when the temperature maximum of $33{ }^{\circ} \mathrm{C}$ was reached. Thereafter, the $\mathrm{CO}_{2}$ concentration returns to the previous level, and starts increasing slowly from October $15^{\text {th }}$, which is the official start of the heating season.

The reason for such a sharp increase in $\mathrm{CO}_{2}$ concentration is the occurrence of thermal inversion due to the sharp temperature drop, and the low driving force in the atmosphere, which led to the $\mathrm{CO}_{2}$ deposition in the ground level of the atmosphere. As the area of interest is only a few meters above the ground (household level, except for the buildings around the District Heating Plant, which are directly influenced by the plume), it can be assumed that the rest of pollutants will follow the $\mathrm{CO}_{2}$ behaviour. This assumption should be verified by monitoring of the chosen pollutants.

\section{CONCLUSION}

In this paper, a specific methodology for atmospheric conditions monitoring by measuring of wind speed and direction, temperature and $\mathrm{CO}_{2}$ concentration is presented. The proposed methodology shows large possibilities for quantitative estimation of the air quality. As concentration levels of $\mathrm{CO}_{2}$ are easily and precisely measured, the proposed methodology gives a relatively cheap and very precise system of quantitative air quality monitoring. The results obtained shows that it is possible to track the plum from the District Heating Plant chimney (56 m high) and to assess its influence on the surrounding buildings and households, which are only few hundred meters away and up to $50 \mathrm{~m}$ high.

As the wind is the most influential parameter for pollution diffusion processes, it is possible to combine continuous $\mathrm{CO}_{2}$ measurements with the sampling techniques for different pollutants in order to obtain real time monitoring of the areas in which the pollution sources originate mostly from combustion processes (which is almost everywhere, except near the large chemical plants). Such methodology should improve our knowledge of the air quality in, primary, highly populated areas.

The chosen monitoring sites covers all types of urban environment in the city of Niš, namely the suburbia with low traffic and medium population density (Monitoring Site 1), city centre with high traffic, high population density and urban canyon structure (Monitoring Site 2) and green and forest area (Control monitoring site). It can be concluded that the methodology presented is acceptable for various monitoring schemes in urban, as well in rural and natural (uninhabited) areas. 
The developed data logger with original software allows easy implementation of the proposed methodology, considering the relatively low price of the instrumentation combined with high quality sensors used. The system is very flexible and can be extended for measuring various air pollutants $\left(\mathrm{CO}, \mathrm{H}_{2} \mathrm{O}, \mathrm{SO}_{x}, \mathrm{NO}_{x}\right.$, VOC, etc.), which makes it useful for validation of numerical simulations. Such data are very valuable for indoor air quality studies, as the outdoor and indoor environment inevitably influence each other.

Hopefully, beter understanding of atmospheric phenomena, as well as the pollution dispersion, will lead to understanding of necesity to keep, and even improve the quality of the entire environment.

\section{REFERENCES}

[1] Urban Air Pollution - European Aspects, J. Fenger, O. Hertel, F. Palmgren (Eds.), Kluwer Academic Publishers, Dordrecht, 1998.

[2] C. Wood, Planning Pollution Prevention, Heinemann Newnes, Oxford, 1989.

[3] W.J. Coirier, S. Kim, CFD Modeling for Urban Area Contaminant Transport and Dispersion: Model Description and Data Requirements, Sixth Symposium on the Urban Environment, The $86 \mathrm{t}^{\mathrm{h}}$ AMS annual meeting, Atlanta, USA, 2006.

[4] S.R. Hanna, J.C. Chang, D.G. Strimaitis, Hazardous gas model evaluation with field observations. Atmos. Environ. 27A (1993) 2265-2285.

[5] R.G. Izarra, Second moment modeling for the numerical simulation of passive scalar dispersion in urban environ- ments, PhD Thesis, Fachbereich Maschinenbau der Universität Siegen, 2009.

[6] P. Živković, G. Ilić, M. Tomić, M. Vukić, M.Ž. Stevanović, Ž.ž. Stevanović, O. Ogrizović, Procena zagađenja vazduha na teritoriji Grada Niša, International Symposium Power Plants 2010, Vrnjačka Banja, Serbia, 2010 (published on CD, ISBN: 978-86-7877-020-3).

[7] P. Živković, G. Ilić, M. Vukić, Measurements of $\mathrm{CO}_{2}$ distribution in free atmosphere, Proceedings of the $5^{\text {th }}$ Dubrovnik Conference on Sustainable Development of Energy, Water and Environment Systems, Dubrovnik, Croatia, 2009 (published on CD: ISBN: 978-953-6313-98$3)$.

[8] Y.-C. Chan, O. Hawas, D. Hawker, P. Vowles, D.D. Cohen, E.D. Stelcer, R. Simpson, G. Golding, E. Christensen, Using multiple type composition data and wind data in PMF analysis to apportion and locate sources of air pollutants, Atmos. Environ. 45 (2011) 439-449.

[9] M.B. Selsted, P. Ambus, A. Michelsen, L. van der Linden, K.S. Larsen, P. Kim, T.N. Mikkelsen, C. Beier, Measurement of carbon dioxide fluxes in a free-air carbon dioxide enrichment experiment using the closed flux chamber technique, Atmos. Environ. 45 (2011) 208-214.

[10] N. Sparks, R. Toumi, Remote sampling of a $\mathrm{CO}_{2}$ point source in an urban setting, Atmos. Environ. 44 (2010) 5287-5294.

[11] Y. Lei, Q. Zhang, C. Nielsen, K. He Beier, An inventory of primary air pollutants and $\mathrm{CO}_{2}$ emissions from cement production in China, 1990-2020, Atmosp. Environ. 45 (2011) 147-154.

[12] D.M. Ugrinov, A.M. Stojanov, Merenje zagađenja vazduha benzenom u gradu Pančevu, Hem. ind. 65 (2011) 211-217. 


\section{IZVOD}

\section{SPECIFIČNI PRISTUP KONTINUALNOM PRAĆENJU KVALITETA VAZDUHA}

Predrag M. Živković ${ }^{1}$, Mladen A. Tomić ${ }^{1}$, Gradimir S. Ilić ${ }^{1}$, Mića V. Vukić1, Žana Ž. Stevanović ${ }^{2}$

${ }^{1}$ Univerzitet u Nišu, Mašinski fakultet, Niš, Srbija

${ }^{2}$ Univerzitet u Beogradu, Institut za nuklearne nauke Vinča, Laboratorija za termotehniku i energetiku, Beograd, Srbija

(Naučni rad)

Nagli razvoj industrije u dvadesetom veku uz nagli porast intenziteta saobraćaja od sedamdesetih godina prošlog veka doveo je probleme zagađenja vazduha na vrh prioriteta vezanih za kvalitet života. Poznato je da su procesi sagorevanja, kako u saobraćajnim sredstvima, tako i u energetskim i ložištima u domaćinstvima, oni koji čine veliku većinu zagađenja vazduha. Gradska toplana „Krivi Vir“ nalazi se u samom gradskom jezgru Niša, u visoko urbanizovanoj zoni u kojoj živi oko 50.000 ljudi. Najbliže zgrade se nalaze na par stotina metara od toplane i slične su visine kao i dimnjak, tako da su izložene direktnom uticaju perjanice, što je bilo veoma uočljivo u periodu dok je kao energent korišćen mazut. Imajući sve ovo u vidu, neizbežno se nameće potreba za što jednostavnijim, jevtinijim, a istovremeno i dovoljno preciznim sistemom kontinualnog praćenja stanja vazduha. Kako je trenutna praksa prikupljanje uzoraka na jednom mestu u gradu, jednom ili dva puta dnevno, to se ne može sa sigurnošću utvrditi na koji način će polutanti difundovati u okolinu, a pogotovo ne u realnom vremenu. Ranija praksa je bila upotreba $\mathrm{SF}_{6}$ kao markera, ali je on zabranjen od početka 2006. Kako je $\mathrm{CO}_{2}$ najzastupljeniji i inertni produkt sagorevanja većine gorivih materija, a njegova koncentracija u atmosferi (preko 390 ppm) omogućava relativno jednostavno, jevtino i precizno merenje, a i zbog relativno malih dimenzija posmatrane oblasti $\left(16 \mathrm{~km}^{2}\right.$ gradskog jezgra Niša), to je on izabran kao reprezent difuzije polutanata, prvenstveno iz Gradske toplane. Postojeći podaci govore da je Gradska toplana izvor oko $31 \% \mathrm{CO}_{2}$ u Nišu, saobraćaj oko $38 \%$, a ostatak je pojedinačno loženje i drugi izvori. Jasno je da se posebna pažnja mora posvetiti samoj Gradskoj toplani. U ovom radu je prikazana specifična metodologija za kontinualno praćenje podataka o brzini i pravcu vetra, temperaturi i koncentraciji $\mathrm{CO}_{2}$. Dat je opis eksperimentalne instalacije, sa karakteristikama korišćenih senzora i softvera razvijenog za prikupljanje podataka. Na kraju je dat uporedni prikaz rezultata merenja sa dva merna mesta, kao i njihova analiza. Dati merni sistem je pokazao da je sposoban da kontinualno prati stanje atmosfere. U sklopu sa pratećim softverom primenljiv je za detaljnije praćanje stanja atmosfere, u zavisnosti od potrebe. Analizom podataka je utvrđeno da su dobijeni rezultati realni i da se ponašaju u skladu sa dnevnim i sezonskim promenama u atmosferi. Oformljena baza podataka se može upotrebiti za validaciju numeričkih eksperimenata, kao osnova za analizu stanja atmosfere, uticaja na kvalitet vazduha u prostorijama, kao i na životnu sredinu.
Ključne reči: Kvalitet vazduha • Stanje atmosfere • Akvizicioni softver • Merenje vetra $\bullet \mathrm{CO}_{2}$ 